BŁAŻEJ OSOWSKI

Uniwersytet im. Adama Mickiewicza w Poznaniu

ORCID: 0000-0002-4226-1378

e-mail: blazej.osowski@amu.edu.pl

\author{
GAROWAĆ - \\ O PEWNYM MAŁO ZNANYM, A WIELOZNACZNYM \\ CZASOWNIKU
}

Garować to wyraz należący współcześnie przede wszystkim do potocznej odmiany polszczyzny. Najnowszy słownik polszczyzny (WSJP) wymienia cztery znaczenia $\mathrm{z}$ nią związane, ponadto jedno regionalne i jedno specjalistyczne. Nie jest to jednak pełen repertuar znaczeń tego czasownika ${ }^{1}$. Niniejsza praca stanowi studium semantyczne tego słowa, w którym przedstawiona zostanie kwerenda słownikowa, repertuar współczesnych znaczeń oraz wewnętrzna motywacja cech semantycznych leksemu (Tokarski 2013: 200), którą w niniejszej pracy nazywać będę filiacją znaczeń.

W świetle danych leksykograficznych czasownik garować pojawia się dość późno, zna go bowiem dopiero SL (w SStp, SXVI, SXVII brak odpowiedniego hasła). Można w nim znaleźć dwa znaczenia - pierwsze odnoszące się do nacinania drzew (gare wyrabać) i drugie związane $\mathrm{z}$ nautyką (garnie wiatr $=$ bokiem $w$ żagle dmie). Znaczenia te powtarza SWil. SW odnotowuje cztery homonimiczne hasła, z czego dwa są kontynuowane ze słowników wcześniejszych, dwa zaś dodano: I 'wycinać w drzewie garę, wyżłabiać dziurę', II 1. fl.[isackie] Garuje żagiel 'przyciągać go pod wiatr garami', 2. mor.[skie] (o wietrze) 'dąć z boku, zawiewać', III cukier.[nicze] i piek. [arskie] (o cieście) 'rosnąć, fermentować, ruszać się, podchodzić', IV (o metalach) 'czyścić'. W SJPD są dwa homonimiczne czasowniki: I garować 'o cieście: rosnąć, podchodzić, fermentować', II garować - żegl.[arskie] a) 'nastawiać reje z żaglami odpowiednio do kierunku wiatru', b) 'o wietrze: dąc z boku, w kierunku ukośnym'.

\footnotetext{
${ }^{1}$ Należy jednak pamiętać, że jak zaznaczają autorzy WSJP, prace „nad powiększaniem słownika trwają, nowe hasła są publikowane sukcesywnie, aktualizuje się także hasła starsze, dodając do nich świeżo powstałe znaczenia" (Wstęp). Informacje zawarte w niniejszym tekście odnoszą się do stanu WSJP z grudnia 2020. Drugą przyczyną rozbieżności może być baza materiałowa WSJP, tj. Narodowy Korpus Języka Polskiego, korpus pomocniczy IJP PAN, polski Internet, własna ekscerpcja haseł oraz inne zasoby leksykograficzne (Zasady: 6), podczas gdy w niniejszym artykule oparto się na danych ankietowych, a więc odwołujących się do świadomości językowej użytkowników polszczyzny.
} 
W PSWP są dwa hasła garować. Pierwsze, pochodzące od niem. gären, ma pięć podznaczeń: 1. spożywczy, kulinarny 'o cieście drożdżowym: zwiększać objętość przed pieczeniem, smażeniem', 2. spożywczy 'gotować produkty żywnościowe w gorącej cieczy poniżej temperatury wrzenia', 3. regionalny, potoczny 'spać, zwłaszcza długo, do późna', 4. uczniowski 'powtarzać klasę, repetować', 5. przestępczy 'przebywać w areszcie, odbywać karę w zakładzie karnym lub poprawczym'. Drugie hasło, pochodzące $\mathrm{z}$ holenderskiego geeren, ma dwa podznaczenia, oba związane z żeglarstwem - 1. 'o wietrze: dąć ukośnie', 2. 'nastawiać reje z żaglami odpowiednio do kierunku wiatru'.

WSJP odnotowuje jedno hasło z podznaczeniami: 1a. spoż.[ywcze] 'powodować, żeby ciasto urosło', 1b. spoż.[ywcze] 'o cieście: rosnąć, 2. pot.[oczne] 'odbywać karę pozbawienia wolności', 3. pot.[oczne] 'ciężko pracować', 4. pozn.[ańskie] 'spać do późna', 5. pot.[oczne] 'pić alkohol', 6. pot.[oczne] 'czekać zbyt długo, przebywając w jednym miejscu'.

Poza znaczeniem słowniki podają źródłosłów. Hol. geeren ufundowało znaczenia żeglarskie (wg SW, SJPD, PSWP). Znaczenie związane z leśnictwem wg SW pochodzi od rzeczownika gara (ukr. gara, może z rum. gaură 'dziura, otwór, luka'). WSJP dla 'ciężko pracować' podaje niem. gehren lub gar machen 'czyścić (o metalach)', zaś dla 'pić alkohol' - gar 'menel'. Niem. garen (SJPD, WSJP)/ gähren (SW, PSWP) dało znaczenia 'spać', 'powtarzać klasę', 'przebywać w areszcie' (PSWP) oraz znaczenia spożywcze (SW, PSWP, WSJP), od którego wg WSJP wyewoluowało 'spać do późna' i 'czekać długo', zaś z tego ostatniego - 'odbywać karę'.

Jak widać z powyższego przeglądu poszczególne słowniki różnią się między sobą zestawem podawanych znaczeń, postrzeganiem relacji zachodzących między nimi (polisemia czy homonimia) oraz określaniem źródłosłowu (głównie chodzi tu o filiację między poszczególnymi znaczeniami, ale także wskazywanie języka-źródła).

Jak się okazuje, przedstawiony repertuar znaczeń może zostać jeszcze uzupełniony. W tym celu przeprowadzono ankietę internetową złożoną z 28 pytań, spośród których jedno brzmiało: Co znaczy GAROWAĆ? Zaproponowano trzy odpowiedzi: 'spać długo', 'rosnąć: o cieście', słowo jest nieznane. Uczestnicy mogli wybrać jedną z nich, kilka i/lub dopisać własną. Zebrano 2550 ankiet, z czego 44 nie zawierały odpowiedzi na interesujące nas tu pytanie, 33 zawierały odpowiedź typy nie wiem / nie dotyczy, zaś 1171 ankiet zawierało odpowiedź słowo jest nieznane. Oznacza to, że jedynie w 1302 ankietach pojawiły się pozytywne odpowiedzi, tj. niewiele ponad połowa odpowiadających $(51 \%)$ zna słowo garować. Dlatego też w tytule artykułu określono je jako mało znane.

Z kolei na jego wieloznaczność wskazuje 28 znaczeń ustalonych na podstawie ankiety. Widać zatem, że ankietowani znacząco uzupełnili dotychczas zarejestrowany w słownikach zbiór. Można zatem za autorkami artykułu o nieodnotowanych w słownikach współczesnej polszczyzny formacjach feminatywnych powtórzyć, że obserwujemy ewolucję uzusu a nieodnotowane znaczenia tworzą swoisty suplement do wykorzystywanych źródeł (Piotrowicz, Witaszek-Samborska 2015: 96). Udzielone odpowiedzi zostały połączone w typy, ponieważ odpowiedzi ankietowanych nie zawsze miały charakter definicyjny, często raczej egzemplifikacyjny lub kontek- 
stowy $^{2}$. Konieczne stało się więc wprowadzenie pewnych uogólnień, by materiał nie popadł w zbytnią drobiazgowość wyróżnionych znaczeń.

Celem artykułu jest przedstawienie repertuaru zarejestrowanych znaczeń wg liczebności (przy uwzględnieniu, jeśli będą istotne, danych o charakterze geograficznym i socjologicznym), a następnie zaproponowanie schematu filiacji znaczeń ${ }^{3}$. Niniejszy tekst wpisuje się zatem w nurt prac wykorzystujących zarówno osiągnięcia leksykografii, jak i badań empirycznych semantyki opartych na danych ankietowych (por. Gatkowska 2017: 122).

Najpopularniejsze spośród odnotowanych znaczeń to 'przebywać w więzieniu (rzadziej: w areszcie)' (507 odpowiedzi). Jest ono znane w całym kraju, jednak występują pewne różnice frekwencyjne. Najpopularniejsze jest na Mazowszu $(+9,5)$, zaś najmniej popularne w Wielkopolsce $(-12,1)^{4}$. Również analiza danych socjologicznych ankietowanych dostarcza ciekawych wniosków. Garować 'przebywać w więzieniu’ można określić jako leksem męski (+15,5\%), wielkomiejski $(+10,7 \%)$

Tabela 1. Najpopularniejsze znaczenia garować wg województw

\begin{tabular}{|l|c|c|c|c|c|c|c|}
\hline Województwo & $\begin{array}{c}\text { Cała ankie- } \\
\text { ta (w \%) }\end{array}$ & $\begin{array}{c}\text { 'przebywać } \\
\text { w więzieniu' }\end{array}$ & $\begin{array}{c}\text { 'długo } \\
\text { spać' }\end{array}$ & $\begin{array}{c}\text { 'o cieście: } \\
\text { rosnąć }\end{array}$ & $\begin{array}{c}\text { 'powtarzać } \\
\text { klasę' }\end{array}$ & $\begin{array}{c}\text { 'przebywać } \\
\text { wbrew woli' }\end{array}$ & 'pić' \\
\hline Dolnośląskie & 6,9 & $+1,4$ & -4 & $-2,2$ & $+3,2$ & $+1,4$ & $-4,0$ \\
\hline Kuj.-pomorskie & 4,6 & $-1,8$ & $+10,1$ & $-2,6$ & $+3,3$ & $+1,7$ & $+1,3$ \\
\hline Lubelskie & 4,4 & $+0,7$ & $-2,7$ & $-2,4$ & $+0,1$ & $+1,9$ & $+4,4$ \\
\hline Lubuskie & 2,7 & $+0,5$ & $-1,5$ & $-0,4$ & $-0,5$ & $+3,6$ & $-2,7$ \\
\hline Łódzkie & 5,4 & $+1,5$ & $-2,0$ & $-1,7$ & $+3,6$ & $-5,4$ & $-2,5$ \\
\hline Małopolskie & 7,6 & $-0,5$ & $-6,6$ & $-4,2$ & $-3,1$ & $-1,3$ & $-7,6$ \\
\hline Mazowieckie & 17,5 & $+9,5$ & $-15,3$ & $-13,1$ & $-0,6$ & $+22,1$ & $+17,8$ \\
\hline Opolskie & 1,5 & $-0,1$ & $-1,5$ & $+0,8$ & $-1,5$ & $-1,5$ & $-1,5$ \\
\hline Podkarpackie & 3,5 & $-0,1$ & $-3,5$ & $-1,2$ & $-0,1$ & $+2,8$ & $-0,6$ \\
\hline Podlaskie & 2,5 & $+0,9$ & $-2,3$ & $-1,8$ & $+0,9$ & $-0,4$ & $-2,5$ \\
\hline Pomorskie & 5,2 & $-1,3$ & $-0,5$ & $-1,5$ & $+0,4$ & $-3,1$ & $+6,3$ \\
\hline Śląskie & 9,0 & $-1,7$ & $-6,1$ & $-1,3$ & 0 & $-2,7$ & $-0,2$ \\
\hline Siętokrzyskie & 2,8 & $+0,4$ & $-2,3$ & $-0,1$ & $+1,7$ & $-2,8$ & $+6,0$ \\
\hline Warm.-mazur. & 2,2 & $+0,6$ & $-1,0$ & $-1,5$ & $-1,1$ & $-0,1$ & $-2,2$ \\
\hline Wielkopolskie & 18,0 & $-12,1$ & $+39,2$ & $+35,7$ & $-15,8$ & $-18,0$ & $-9,2$ \\
\hline Zachodniopom. & 3,7 & $+0,4$ & $-1,2$ & $-0,7$ & $+5,3$ & $-1,6$ & $+2,2$ \\
\hline Inne & 2,4 & $+1,9$ & $-0,7$ & $-1,7$ & $+4,3$ & $+3,9$ & $-2,4$ \\
\hline Razem & 2550 & 507 & 407 & 298 & 89 & 48 & 34 \\
\hline
\end{tabular}

Źródło: opracowanie własne.

2 O kwestii definiowania regionalizmów przez nieprofesjonalistów por.: Piotrowicz, Witaszek-Samborska 2009.

3 Podobną metodę, przedstawiania zmian znaczenia prototypowego barwy zielonej, stosowała Waszakowa 2003.

${ }^{4}$ Zapisy typu $+9,5 \%$ lub -12,1\% odnoszą się do danych z Tabel 1-4. Oznaczają, że w odpowiedniej kategorii danych nastąpił przyrost lub spadek o wskazaną wartość w stosunku do całej ankiety. Jeśli więc osoby deklarujące miejsce zamieszkania na terenie woj. mazowieckiego stanowiły 17,5\% wszystkich ankietowanych, to na w powyższym przykładzie znaczenie 'przebywać w więzieniu' zadeklarowało 9,5\% więcej osób z Mazowsza, tj. 27\%. 
Tabela 2. Najpopularniejsze znaczenia garować wg płci

\begin{tabular}{|l|c|c|c|c|c|c|c|}
\hline \multicolumn{1}{|c|}{ Płeć } & $\begin{array}{c}\text { Cała } \\
\text { ankieta } \\
\text { (w \%) }\end{array}$ & $\begin{array}{c}\text { 'przebywać } \\
\text { w więzie- } \\
\text { niu' }\end{array}$ & $\begin{array}{c}\text { 'długo } \\
\text { spać' }\end{array}$ & $\begin{array}{c}\text { 'o cieście: } \\
\text { rosnąć' }\end{array}$ & $\begin{array}{c}\text { 'powtarzać } \\
\text { klasę' }\end{array}$ & $\begin{array}{c}\text { 'przebywać } \\
\text { wbrew } \\
\text { woli' }\end{array}$ & 'pić' \\
\hline Kobieta & 68,2 & $-15,1$ & $+4,5$ & $+10,3$ & $-7,5$ & $-3,6$ & $-12,3$ \\
\hline Mężczyzna & 28,8 & $+15,5$ & $-4,7$ & $-8,7$ & $+9,4$ & $+6,6$ & $+12,4$ \\
\hline Inna & 0,8 & 0 & $-0,3$ & $-0,5$ & $-0,8$ & $-0,8$ & $+2,1$ \\
\hline Nie podano & 2,2 & $-0,4$ & $+0,5$ & $-1,2$ & $-1,1$ & $-2,2$ & $-2,2$ \\
\hline Razem & 2550 & 507 & 407 & 298 & 89 & 48 & 34 \\
\hline
\end{tabular}

Źródło: opracowanie własne.

Tabela 3. Najpopularniejsze znaczenia garować wg typu miejsca zamieszkania

\begin{tabular}{|l|c|c|c|c|c|c|c|}
\hline \multicolumn{1}{|c|}{$\begin{array}{c}\text { Miejsce } \\
\text { zamieszkania }\end{array}$} & $\begin{array}{c}\text { Cała } \\
\text { ankieta } \\
(\mathrm{w} \%)\end{array}$ & $\begin{array}{c}\text { 'przebywać } \\
\text { w więzie- } \\
\text { niu' }\end{array}$ & $\begin{array}{c}\text { 'długo } \\
\text { spać' }\end{array}$ & $\begin{array}{c}\text { 'o cieście: } \\
\text { rosnąć' }\end{array}$ & $\begin{array}{c}\text { 'powtarzać } \\
\text { klasę' }\end{array}$ & $\begin{array}{c}\text { 'przebywać } \\
\text { wbrew } \\
\text { woli' }\end{array}$ & 'pić' \\
\hline Na wsi & 16,7 & $-6,6$ & $+5,7$ & $+4,1$ & $-5,5$ & $-8,4$ & $+0,9$ \\
\hline $\begin{array}{l}\text { Miasto } \\
\text { do 20 tys. }\end{array}$ & 12,4 & $-2,1$ & $+4,8$ & $+5,7$ & 0 & $+2,2$ & $-3,6$ \\
\hline $\begin{array}{l}\text { Miasto } \\
20 \text { tys.-100 tys. }\end{array}$ & 16,5 & $-1,7$ & $+2,7$ & $-0,7$ & $-7,5$ & $-8,2$ & $-10,6$ \\
\hline $\begin{array}{l}\text { Miasto powyżej } \\
100 \text { tys. }\end{array}$ & 53,6 & $+10,7$ & $-14,0$ & $-9,6$ & $+13,8$ & $+15,2$ & $+14,0$ \\
\hline Nie podano & 0,8 & $-0,2$ & $+0,9$ & $+0,5$ & $-0,8$ & $-0,8$ & $-0,8$ \\
\hline Razem & 2550 & 507 & 407 & 298 & 89 & 48 & 34 \\
\hline
\end{tabular}

Źródło: opracowanie własne.

Tabela 4. Najpopularniejsze znaczenia garować wg przedziałów wiekowych

\begin{tabular}{|l|c|c|c|c|c|c|c|}
\hline Rok urodzenia & $\begin{array}{c}\text { cała } \\
\text { ankieta } \\
\text { (w \%) }\end{array}$ & $\begin{array}{c}\text { 'przebywać } \\
\text { w więzie- } \\
\text { niu' }\end{array}$ & $\begin{array}{c}\text { 'długo } \\
\text { spać' }\end{array}$ & $\begin{array}{c}\text { 'o cieście: } \\
\text { rosnąć' }\end{array}$ & $\begin{array}{c}\text { 'powtarzać } \\
\text { klasę' }\end{array}$ & $\begin{array}{c}\text { 'przebywać } \\
\text { wbrew } \\
\text { woli' }\end{array}$ & 'pić' \\
\hline $1930-1939$ & 0,1 & $-0,1$ & $+0,1$ & $-0,1$ & $-0,1$ & $-0,1$ & $-0,1$ \\
\hline $1940-1949$ & 0,7 & $+0,3$ & $+0,3$ & $+0,6$ & $-0,7$ & $-0,7$ & $-0,7$ \\
\hline $1950-1959$ & 3,4 & $+3,7$ & $-0,5$ & $+0,3$ & 0 & $-3,4$ & $-3,4$ \\
\hline $1960-1969$ & 7,3 & $+5,5$ & $+1,8$ & $+3,8$ & $-0,6$ & $-2,5$ & $-1,4$ \\
\hline $1970-1979$ & 20,1 & $+3,6$ & $+2,5$ & $+2,0$ & $+9,1$ & $+21,6$ & $+24,0$ \\
\hline $1980-1989$ & 31,1 & $-0,7$ & $+1,8$ & $+0,1$ & $+4,9$ & $+6,4$ & $+7,1$ \\
\hline $1990-1999$ & 29,4 & $-8,5$ & $-3,8$ & $-5,6$ & $-6,9$ & $-10,6$ & $-17,6$ \\
\hline Po r. 2000 & 4,9 & $-4,1$ & $-2,4$ & $-1,2$ & $-3,8$ & $-4,9$ & $-4,9$ \\
\hline Nie podano & 3,0 & $+0,4$ & $+0,2$ & 0 & $-1,9$ & $-3,0$ & $-3,0$ \\
\hline Razem & 2550 & 507 & 407 & 298 & 89 & 48 & 34 \\
\hline
\end{tabular}

Źródło: opracowanie własne.

i charakterystyczny dla osób urodzonych w przedziale 1950-1979. Pokrywa się to z intuicją ankietowanego urodzonego w 1976 roku, który określa to znaczenie jako przestarzałe; zaś ankietowana urodzona w 1991 roku nie jest pewna znaczenia wyrazu (Chyba siedzieć w więzieniu, ale nwm [nie wiem - B.O.])1.

${ }^{1}$ Cytaty z ankiet przytaczam w ich oryginalnej postaci. 
Drugie co do frekwencji znaczenie 'długo spać' (407) w PWSP określone zostało jako regionalne, zaś w WSJP - jako poznańskie. Ankieta pokazuje, że osoby potwierdzające to znaczenie pochodziły przede wszystkim z woj. wielkopolskiego i kujawsko-pomorskiego, zasięg jest zatem szerszy niż wskazuje na to kwalifikator WSJP. Zróżnicowanie pod względem wieku nie gra tu większej roli, choć widać, że u osób urodzonych po 1990 roku znajomość tego znaczenia spada. Może to być związane $\mathrm{z}$ jego gwarowym pochodzeniem, na co wskazuje przyrost $+5,7 \%$ wśród mieszkańców wsi i spadek $-14 \%$ w dużych miastach. Niemniej, i tam znaczenie 'długo spać' występuje, należy je więc za PWSP i WSJP określić jako regionalne, nie tylko gwarowe.

Potwierdzane od SW znaczenie 'o cieście: rosnąć' (298) od SJPD podawane jest jako pierwsze, tymczasem frekwencja $\mathrm{w}$ ankiecie lokuje je dopiero na miejscu trzecim, po 'przebywać w więzieniu' i 'długo spać'. Co więcej, jedynie w woj. wielkopolskim odnotowano znaczącą liczbę potwierdzeń tego znaczenia, natomiast we wszystkich pozostałych (poza opolskim) zanotowano niewielkie spadki w stosunku do udziału poszczególnych województw w całej ankiecie. W woj. mazowieckim różnica jest znacząca i wynosi $-13,1 \%$. Ponadto znajomość tego znaczenia uwarunkowana jest płcią (kobiety $+10,3 \%$, mężczyźni $-8,7 \%$ ), co powiązać można $\mathrm{z}$ większą u kobiet znajomością wiedzy kulinarnej, miejscem zamieszkania (wieś $+4,1 \%$, małe miasta $+5,7 \%$, średnie miasta $-0,7 \%$ i duże miasta $-9,6 \%$ ) oraz wiekiem (u osób urodzonych po 1990 roku spadek udziału w porównaniu z całą ankietą). Być może zatem znaczenie 'o cieście: rosnąć' zaczyna przechodzić do grupy słownictwa przestarzałego i regionalnego (wielkopolskiego) .

Znaczenie 'powtarzać klasę; repetować' (89) znane jest w całej Polsce. (Niekiedy dochodzi do rozszerzenia znaczenia: 'powtarzać rok studiów'). Jedynie w Wielkopolsce, gdzie dominują znaczenia 'długo spać' i 'o cieście: rosnąc', jest ono słabiej znane $(-15,8 \%)$. Można je natomiast wiązać z dużymi miastami $(+13,8 \%)$ oraz pokoleniem lat 1970-1989. Osoby urodzone później rzadziej znają to znaczenia; przesuwa się ono zatem do sfery przestarzałych środków językowych. Co ciekawe, podobnie określiły to znaczenie dwie osoby urodzone w latach 70 . XX wieku.

$\mathrm{Z}$ tym omówionym wyżej znaczeniem oraz z 'przebywać w więzieniu' powiązane jest ogólniejsze 'przebywać gdzieś pod przymusem, wbrew sobie' (48). Ankietowani podawali wiele przykładów sytuacji, w których można zastosować to znaczenie, z czego trzy powtarzały się szczególnie często. Dwa pierwsze odnoszą się do dzieci i młodzieży - 'zostać w domu wbrew chęci ze względu na nakaz rodziców' (dostać od rodziców zakaz wychodzenia $z$ domu itd.; mieć szlaban $w$ domu) oraz 'zostać w szkole po lekcjach za karę' (siedzieć w kozie). Trzecie znaczenie odnosi się do osób dorosłych i jest związane z pracą - 'zostać po godzinach' (gdzie on jest? jeszcze garuje w pracy; wczoraj do wieczora w pracy garowal; siedzieć dlugo wykonujac monotonna pracę). Znaczenie to szczególnie często podawały osoby z Mazowsza, częściej mężczyźni niż kobiety, osoby z dużych miast i urodzone w latach 1970-1989. Wśród młodszych znajomość tego znaczenia drastycznie spada.

\footnotetext{
${ }^{5}$ Przynajmniej, jeśli bierze się pod uwagę frekwencję - por. pojęcie regionalizmu frekwencyjnego (Handke 1986-1987).
} 
Kolejne co do frekwencji znaczenie czasownika garować to 'pić alkohol' (34). Niekiedy było ono wzbogacane o dodatkowe informacje, np. pić kilka dni pod rzad; Pić na umór; Pić dużo alhololu; pić dużo alkoholu, i często; Pić alkohol prosto z butelki; upijać się; Pić alkohol (od wielu godzin, nie w lokalu). Znaczenie to częściej podawały osoby $\mathrm{z}$ woj. mazowieckiego, pomorskiego i świętokrzyskiego, z dużych miast, urodzone w latach 70. XX wieku, mężczyźni.

Znaczenie 'czekać długo' pojawiło się w 24 ankietach. W odpowiedziach pojawiły się dodatkowe elementy typu 'być zmuszonym do czekania', 'czekać, nie wiedząc, kiedy ten stan się skończy', 'czekać bezczynnie, nudząc się’, co dość dobrze oddaje przykład przywołany przez jedną z ankietowanych: Garować na lotnisku.

Pozostałe znaczenia są rzadsze: 'długo gdzieś przebywać' (11), 'jechać szybko autem' (9), 'leniuchować' (9), 'chrapać' (7), 'ciężko pracować' (5), 'fermentować' (5), 'gasić papierosa' (5), 'gotować' (5), 'odpoczywać' (4), 'mieć kaca' (3), 'wagarować' (3), 'imprezować, pijąc alkohol' (2), 'o jedzeniu: psuć się' (2), 'siedzieć długo u kogoś' (2), 'cierpieć na schorzenia psychiczne' (1), 'grać głośno na gitarze' (1), 'o głowie: boleć' (1), 'o pogodzie: być gorąco' (1), 'przekraczać prędkość' (1), 'przygotowywać obiad' (1), 'służyć w wojsku’ (1), 'spać gdzieś bez pozwolenia właściciela' (1), 'śmierdzieć' (1), 'śpiewać po francusku' (1), 'zionąć alkoholem' (1).

Jeśli chodzi o gamę znaczeń czasownika garować, to dla większości z nich podstawę stanowi 'fermentować' (por. schemat $1^{6}$ ), które przejęto razem z niemiecką pożyczką gären (Chodera, Kubica 1996). Przyjmuję to - ogólniejsze - znaczenie, choć w słowniku niemieckich zapożyczeń w polszczyźnie znaczenie niem. garen zawęża się do 'beim Kuchen: aufgehen, fermentieren' - 'o cieście: rosnąć, fermentować' (de Vincenz, Hentschel: hasło garować III). Od 'fermentować' biorą początek dwa znaczenia $-z$ konotacjami negatywnymi, mniej aktywne motywacyjnie 'o jedzeniu: psuć się', z którego 'śmierdzieć' przez związek 'żywność zepsuta nieprzyjemnie pachnie', oraz neutralne znaczeniowo zawężenie fermentacji do kontekstu kulinarnego (w odniesieniu do ciasta drożdżowego) 'o cieście: rosnąć'. Przyrastanie ciasta jako czynność związana z przygotowywaniem żywności dała znaczenie 'gotować'7, które przez specjalizację doprowadziło do 'przygotowywać obiad'. Od znaczenia 'o cieście: rosnąć' wskazującej na czynność długo trwającą pochodzi 'długo gdzieś przebywać', które jest z kolei podstawą 4 następnych, w których konkretyzacji ulega ogólne znaczenie 'przebywać'. W pierwszym z nich przebywanie polega na czekaniu ('długo czekać'), w drugim - na zostawaniu wbrew swej woli, w trzecim - na przebywaniu u kogoś długo (w gościach), w ostatnim - na spaniu długo. Wszystkie znaczenia poza pierwszym są podstawą do derywacji następnych. 'Zostać gdzieś wbrew woli' może przybrać formę 'ciężko pracować' (jeśli ktoś pracuje w miejscu, którego nie lubi, może to traktować jako czynność wykonywaną wbrew swej woli), 'służyć w wojsku' (znaczenie to zostało ufundowane, gdy służba wojskowa była obowiązkowa), 'przebywać w więzieniu' oraz 'powtarzać klasę', w których obecność semu 'ograniczenia wolności' jest ewidentna. Przebywanie u kogoś długo, np. w gościach, może wiązać się ze wspólnym świętowaniem, co dało znaczenie 'imprezować, pijąc alkohol', na-

\footnotetext{
${ }^{6}$ Wielkość koła oznacza frekwencję ustaloną na podstawie ankiety.

${ }^{7}$ Tu też alternatywna eksplikacja: przejęcie znaczenia bezpośrednio z niemieckiej pożyczki.
} 


\section{Schemat znaczeń}

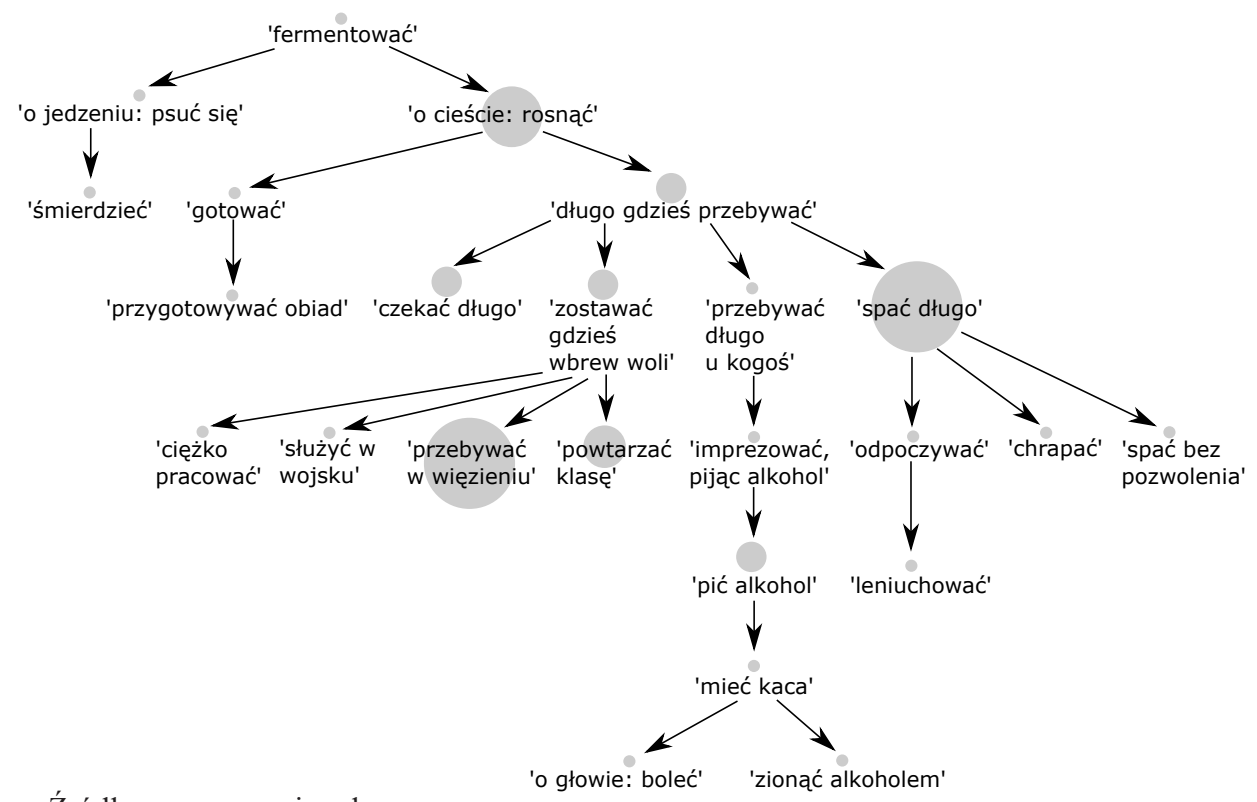

Źródło: opracowanie własne.

stępnie zaś 'pić alkohol', czego skutkiem może być nieprzyjemny stan - 'mieć kaca', który z kolei przejawiać się może jako ból głowy ('o głowie: boleć’) lub odorem alkoholu ('zionąć alkoholem'). Długi sen postrzegany jest jako forma regeneracji i spędzania wolnego czasu, co dało 'odpoczywać', a bierny odpoczynek z kolei dał 'leniuchować'. Ponadto spaniu towarzyszyć może wydawanie charakterystycznego odgłosu (stąd 'chrapać’) lub też spać można gdzieś bez zgody właściciela, np. w akademiku ('spać bez pozwolenia').

Poza schematem znalazły się znaczenia, które trudno wyprowadzić od 'fermentować' i powiązać z innymi. Niem. gären przenośnie używa się jako 'wrzeć, burzyć się' (Chodera, Kubica 1996), co mogło stać się podstawą dla znaczenia odnoszącego się do czynności gwałtownych - 'jechać szybko autem', a to z kolei dla 'przekraczać prędkość'. Garować jako 'o pogodzie: być gorąco' związane jest z poznańskim garówa 'upał', na co wskazuje lokalizacja ankietowanego, który podał to znaczenie (Poznań). Garować jako 'wagarować', 'grać głośno na gitarze' i 'śpiewać po francusku’ jest być może przekształceniem formalnym innych czasowników: wagarować, gitarować, grasejować ('wymawiać spółgłoskę $r \mathrm{z}$ wibracją języczka' - jak w języku francuskim). Nie udało się ustalić motywacji dla 'gasić papierosa' i 'cierpieć na schorzenia psychiczne'.

Podsumowując, należy podkreślić, że znajomość wyrazu garować jest ograniczona; aż 49\% ankietowanych go nie znało. Na podstawie przeprowadzonej ankiety udało się wyodrębnić 28 jego znaczeń. Niemal wszystkie znaczenia odnotowane w najnowszym słowniku polszczyzny (WSJP) zostały potwierdzone. (W ankiecie nie potwierdzono jedynie znaczenia 1a. 'powodować, żeby ciasto urosło', które być może 
dla niespecjalistów niewiele różniło się od bogato poświadczonego $1 \mathrm{~b}$. 'o cieście: rosnąć'). Kolejność znaczeń wspólnych dla ankiety i WSJP jest jednak inna. Frekwencja ustalona na podstawie ankiety wskazuje, że najczęstszym znaczeniem jest 'przebywać w więzieniu' (w WSJP znaczenie 2.), następnie 'długo spać' (w WSJP - 4.), 'o cieście: rosnąć' (w WSJP - 1b.), następnie 5 znaczeń nieodnotowanych w tym słowniku, dalej: 'pić alkohol' (w WSJP znaczenie 5.), 'długo czekać' (w WSJP - 6.), następnie 4 znaczenia, których brak w WSJP i jako 3. w nim odnotowane 'ciężko pracować' (wg ankiety na pozycji piętnastej). Z oczywistych względów takiego porządku w słowniku nie dałoby się zastosować. W opracowaniach tego typu najczęściej stosuje się określony porządek podawania znaczeń, podczas gdy ten powyżej zaprezentowany oparty jest jedynie na frekwencji. Niemniej, jest to kolejne potwierdzenie stwierdzenia, że - jak to bywa w przypadku każdego słownika - odbija on nie system językowy, lecz jego wizję przedstawioną przez autorów opracowania.

Praktycznym zastosowaniem niniejszych ustaleń może być proponowane przez Piotra Żmigrodzkiego uwzględnienie opisu semantycznego przy sporządzaniu opisu znaczenia w słowniku (Żmigrodzki 2008: 46). Oczywiście zdaję sobie sprawę, że opracowania w postaci artykułu nie można zawrzeć w definicji słownikowej ze względu na odmienny charakter obu tych gatunków. 28 znaczeń czasownika garować to stanowczo za dużo nawet na słownik nieograniczony limitem miejsca. Dane z ankiety dają jednak asumpt do korekty określania znaczenia 'długo spać' jako poznańskiego. Autorzy WSJP skrócenia kwalifikatorów dotyczących zasięgu geograficznego typu pozn.[ańskie], warsz.[awskie] itd. rozumieją szeroko ,jako odnoszące się nie tylko do danego miasta, ale i całego regionu (obszaru językowego), którego dane miasto jest albo było stolicą” (Zasady: 35). Znaczenie 'długo spać’ jest co prawda znane w Wielkopolsce, której stolicą jest Poznań, ale także na Kujawach, których z Poznaniem łączyć już nie można. Ankieta pokazała ponadto, że znaczenie 'o cieście: rosnąć w coraz większym stopniu nabiera charakteru regionalnego (wielkopolskiego).

\section{Bibliografia}

\section{Źródła}

Chodera J., Kubica S., 1996, Podręczny słownik niemiecko-polski, wyd. 15, Warszawa.

PSWP - Praktyczny słownik współczesnej polszczyzny, red. H. Zgółkowa, t. 1-50, Poznań 1994-2005.

SJPD - Stownik języka polskiego, red. W. Doroszewski, t. 1-11, Warszawa 1958-1969.

SL - S.B. Linde, Stownik języka polskiego, t. 1-6, Warszawa 1807-1814.

SStp - Stownik staropolski, red. S. Urbańczyk, t. 1-11, Kraków 1953-2002.

SW - Słownik języka polskiego, red. J. Karłowicz, A.A. Kryński, W. Niedźwiedzki, t. 1-8, Warszawa 1900-1927.

SWil - A. Zdanowicz i in., Słownik języka polskiego, Wilno 1861. Wersja elektroniczna: https://eswil.ijp.pan.pl/index.php (4.12.2020). 
SXVI - Słownik polszczyzny XVI wieku, t. 1-34, red. M.R. Mayenowa, F. Pepłowski, od t. 35

K. Mrowcewicz, P. Potoniec, Wrocław 1966-1994, Warszawa 1995-.

SXVII - Stownik języka polskiego XVII i 1. połowy XVIII wieku, Kraków 1996-. Wersja elektroniczna: https://sxvii.pl/ (4.12.2020).

de Vincenz A., Hentschel G., Das Wörterbuch der deutschen Lehnwörter in der polnischen Schrift- und Standardsprache, Göttingen-Oldenburg, http://diglib.bis.uni-oldenburg.de/ bis-verlag/wdlp/ (4.12.2020).

WSJP - Wielki słownik języka polskiego, red. P. Żmigrodzki, https://www.wsjp.pl/ (4.12.2020).

\title{
Literatura
}

Gatkowska I., 2017, Dom 'house/home' in empirical lexical networks, „Ethnolinguistic” 28, s. 121-140.

Handke K., 1986-1987, O regionalizmie frekwencyjnym, „Studia Polonistyczne” 14-15, s. 71-76. Piotrowicz A., Witaszek-Samborska M., 2009, O sposobach definiowania regionalizmów wielkopolskich przez uczniów, w: A. Piotrowicz, M. Witaszek-Samborska, Studia na polszczyzna miejska Poznania, Poznań, s. 190-205.

Piotrowicz A., Witaszek-Samborska M., 2015, Kilka uwag o nieodnotowanych $w$ stownikach współczesnej polszczyzny formacjach feminatywnych, „Poznańskie Spotkania Językoznawcze" 29, s. 87-96.

Tokarski R., Znaczenie słowa i zasada wewnętrznej motywacji cech semantycznych, „Poznańskie Studia Polonistyczne. Seria Językoznawcza" 20, z. 2, s. 195-204.

Waszakowa K., 2003, Opis porównawczy znaczeń podstawowej nazwy barwy zielonej w języku polskim, czeskim, rosyjskim, ukraińskim i wietnamskim, w: Studia z semantyki porównawczej. Nazwy barw, nazwy wymiarów, predykaty mentalne, cz. 2, red. R. Grzegorczykowa i K. Waszakowa, Warszawa, s. 49-68.

Wstęp - Wstęp, w: Wielki słownik języka polskiego, red. P. Żmigrodzki, https://www.wsjp.pl/ index.php?pokaz $=$ wstep\&l $=1 \&$ ind $=0$ ?pwh $=0$ (4.12.2020).

Zasady - Wielki słownik języka polskiego PAN. Zasady opracowania, zestawił P. Żmigrodzki, wyd. 4, Kraków 2020, https://www.wsjp.pl/pobieranie/zasady_opracowania_wsjp.pdf (4.12.2020).

Żmigrodzki P., 2008, Stowo - słownik - rzeczywistość. Z problemów leksykografii i metaleksykografii, Kraków.

\section{BŁAŻEJ OSOWSKI}

\section{Garować: a little known Polish verb of various meanings}

\begin{abstract}
Garowac is a word which at present belongs primarily to the colloquial variety of the Polish language. Wielki słownik jezzka polskiego [The Great Dictionary of the Polish Language] mentions 6 meanings of the verb. However, this number does not exhaust the range. The goal of the article is to present the scope of the contemporary meanings of the word. To this end, an online questionnaire was distributed which produced 1,302 replies related to the subject of my interest. The article presents excerpted meanings arranged by prevalence (taking into consideration, if relevant, data of geographic and sociological nature).
\end{abstract}


Next, a scheme of the meanings' affiliation was suggested. Therefore, this text connects with the works using both the achievements of lexicography as well as empirical research into semantics, based on the data from the questionnaires.

Keywords: lexicography, semantics, relations of meaning, Polish language. 